\title{
Water level changes in Polish lakes during 1976-2010
}

\author{
Dariusz WRZESIŃSKI, "Mariusz PTAK \\ Institute of Physical Geography and Environmental Planning, Adam Mickiewicz University, Dzięgielowa 27, \\ 61-680 Poznań, Poland
}

\begin{abstract}
The paper presents the analysis of tendencies in water level changes in 32 lakes in Poland during 1976-2010. Series of monthly, seasonal, and annual precipitation and air temperature for 9 meteorological stations were also studied. The trend analysis for all of the studied series of water levels in lakes showed high spatial and temporal variability. Series of annual water levels in the case of 6 lakes showed statistically significant increasing tendencies, and in 7 lakes, significant decreasing trends. Series of annual amplitudes in the majority of lakes (22) showed a decreasing trend, but they were statistically significant only in three cases. The tendencies for air temperature fluctuations are more statistically significant than precipitation. The key role in determining water level changes is played by local factors, particularly including human economic activity, obscuring the effect of natural factors on water level changes. The paper describes cases of changes in water levels in lakes under anthropopressure related to among others: agricultural irrigations, hydropower infrastructure, water transfers, navigation, or mining.
\end{abstract}

Keywords: lake-level trends; lake-level regime; Mann-Kandell Test; climate change; human activity

\section{Introduction}

Water level changes are among the primary factors affecting the functioning of lakes. The degree of filling lake basins with water is of key importance for the course of a number of processes and phenomena, among others hydrological (Ziverts and Apsite, 2005; Dusini et al., 2009; Rodríguez-Rodríguez et al., 2012), geomorphological (Machowski et al., 2005; Zinke and Bogen, 2013; Castañeda et al., 2015), and biological (Hayashi and van der Kamp, 2007; Nishihiro, 2011). A specific volume of water in a lake and stability of the water table are of high importance from the point of view of human activity. These elements determine the abundance and availability of water resources in lakes, as well as the possibilities of their use in various areas of economy, e.g. industry, agriculture, or tourism. According to Yin et al. (2013), water level changes in lakes are also important for purely technical reasons related to the development of structures along lake shores. Water level changes, their scale, dynamics,

Received: 2015-02-25 Accepted: 2015-06-09

Author: Dariusz WRZESIŃSKI, e-mail: darwrze@amu.edu.pl

"Corresponding author: Mariusz PTAK, e-mail: marp114@wp.pl 
and change tendencies depend on natural (Li et al., 2007; Duo et al., 2009; Singh et al., 2010) and anthropogenic (Konatowska and Rutkowski, 2008; Zhuang et al., 2011) factors. In many cases, the determination of their primary cause is very difficult (Jańczak and Choiński, 1988).

In reference to Polish lakes, the issue of water level changes has been undertaken by many researchers on varied sets of objects, i.e. from individual cases to several tens of lakes (Skibniewski, 1954; Pasławski, 1972; Niewiarowski, 1978; Chlost and Cieśliński, 2005; Michalczyk et al., 2011; Kutyła, 2014; Piasecki and Marszelewski, 2014). Depending on the adopted scope of analysis, the papers show variable tendencies in water level changes, and suggest various reasons for the situation. Studies determining the effect of meteorological conditions on water level changes in lakes in Poland conducted to date particularly refer to the course of precipitation. Air temperature, affecting the evaporation volume, is considered less frequently, although as emphasised by Polderman and Pryor (2004), water level changes in lakes are closely correlated with the variability of both precipitation and evaporation. The key role of these two factors is confirmed by e.g. research on lakes in the Tibetan Plateau (Yao et al., 2014).

The objective of the paper is to present tendencies of water level changes in Polish lakes in the years 1976-2010 in relation to precipitation and air temperature fluctuations. The paper determines the scale and direction of water level changes, and the primary causes of such changes.

\section{Material and methods}

\subsection{Study area}

The territory of Poland includes more than 7000 natural lakes with an area equal to or exceeding 1 ha. They are particularly located in the northern part of the country within the range of the last glaciation. Data for 32 lakes were used in the study (Figure 1).

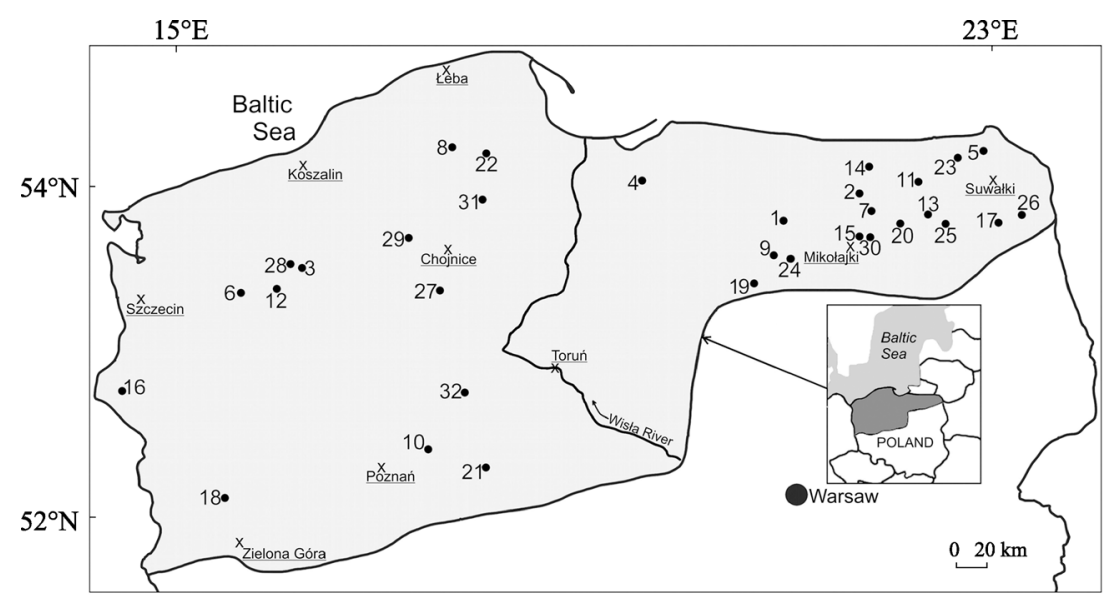

Figure 1 Location of the lakes and meteorological stations

\subsection{Data collected}

Daily observations of water levels provided the basis, for the calculation of monthly, sea- 
sonal, annual, maximum, and minimum water levels, and annual amplitudes. Series of mean monthly and annual air temperatures and precipitation totals for 9 meteorological stations from the years 1976-2010 were also used. All of the data come from the collection of the Institute of Meteorology and Water Management.

The paper also uses information concerning hydrotechnical development included in the study of the National Water Management Authority (www.hydrogeoportal.pl), and in the hydrographic maps of Poland at a scale of 1:50,000. The basic parameters of the lakes are presented in Table 1.

Table 1 Morphometric data of the studied lakes (numbering in accordance with Figure 1)

\begin{tabular}{|c|c|c|c|c|c|}
\hline No & Lake & Area (ha) & $\begin{array}{l}\text { Volume } \\
\text { (thous } \mathrm{m}^{3} \text { ) }\end{array}$ & Average depth (m) & $\begin{array}{l}\text { Maximum } \\
\text { depth (m) }\end{array}$ \\
\hline 1 & Dadaj & 978.0 & 120784.2 & 12.0 & 39.8 \\
\hline 2 & Dejguny & 762.5 & 92617.4 & 12.0 & 45.0 \\
\hline 3 & Drawsko & 1797.5 & 331443.4 & 17.7 & 82.2 \\
\hline 4 & Druzno & 1147.5 & 17352.0 & 1.2 & 2.5 \\
\hline 5 & Hańcza & 291.5 & 120364.1 & 38.7 & 106.1 \\
\hline 6 & Ińsko & 529.0 & 65182 & 11.0 & 41.7 \\
\hline 7 & Jagodne & 872.5 & 82705.2 & 8.7 & 37.4 \\
\hline 8 & Jasień & 575.0 & 48048 & 8.3 & 32.2 \\
\hline 9 & Kalwa & 561.0 & 39468.6 & 7.0 & 31.7 \\
\hline 10 & Lednica & 325.0 & 24397 & 7.0 & 15.1 \\
\hline 11 & Litygajno & 154.5 & 9763.9 & 6.0 & 16.4 \\
\hline 12 & Lubie & 1487.5 & 169880.5 & 11.6 & 46.2 \\
\hline 13 & Łaśmiady & 940.0 & 84607.8 & 9.6 & 43.7 \\
\hline 14 & Mamry & 9851.0 & 1003367.5 & 9.8 & 43.8 \\
\hline 15 & Mikołajskie & 424.0 & 55739.7 & 11.2 & 25.9 \\
\hline 16 & Morzycko & 317.5 & 49826.9 & 14.5 & 60.7 \\
\hline 17 & Necko & 400.0 & 40561.4 & 10.1 & 25.0 \\
\hline 18 & Niesłysz & 526.0 & 34457.6 & 6.9 & 34.7 \\
\hline 19 & Omulew & 504.0 & 22172.7 & 4.3 & 32.5 \\
\hline 20 & Orzysz & 1012.5 & 75326.2 & 6.6 & 36.0 \\
\hline 21 & Powidzkie & 1097.5 & 134776.2 & 11.5 & 46.0 \\
\hline 22 & Raduńskie Górne & 362.5 & 60158.7 & 15.5 & 43.0 \\
\hline 23 & Rospuda Filipowska & 323.5 & 49731.8 & 14.5 & 38.9 \\
\hline 24 & Sasek Wielki & 866.0 & 71194.8 & 8.2 & 38.0 \\
\hline 25 & Selmęt Wielki & 1207.5 & 99463.9 & 7.8 & 21.9 \\
\hline 26 & Serwy & 438.5 & 67181.5 & 14.1 & 41.5 \\
\hline 27 & Sępoleńskie & 157.5 & 7501.6 & 4.8 & 10.9 \\
\hline 28 & Siecino & 740.0 & 104441.7 & 14.1 & 44.2 \\
\hline 29 & Szczytno Wielkie & 565.0 & 51762.5 & 8.0 & 21.4 \\
\hline 30 & Śniardwy & 11487.5 & 660211.8 & 5.8 & 23.4 \\
\hline 31 & Wdzydze & 1417.0 & 220800.0 & 1.2 & 69.5 \\
\hline 32 & Żnińskie Duże & 420.5 & 29492.6 & 6.8 & 11.1 \\
\hline
\end{tabular}

\subsection{Data analysis}

To detect and estimate trends in the time series the Excel template MAKESENS (Mann- 
Kendall test) developed by researchers of the Finnish Meteorological Institute (Salmi et al., 2002), was used.

The Mann-Kendall test is applicable in cases when the data values $x_{i}$ of a time series can be assumed to obey the model

$$
x_{i}=f(t)+\varepsilon_{i},
$$

where $f(t)$ is a continuous monotonic increasing or decreasing function of time and the residuals $\varepsilon_{i}$ can be assumed to be from the same distribution with zero mean. It is therefore assumed that the variance of the distribution is constant in time.

The Mann-Kendall test statistic $S$ is calculated using the formula:

$$
S=\sum_{k=1}^{n-1} \sum_{j=k+1}^{n} \operatorname{sgn}\left(x_{j}-x_{k}\right)
$$

where $x_{j}$ and $x_{k}$ are the annual values in years $j$ and $k, j>k$, respectively, and:

$$
\operatorname{sgn}\left(x_{j}-x_{k}\right)= \begin{cases}1 & \text { if } x_{j}-x_{k}>0 \\ 0 & \text { if } x_{j}-x_{k}=0 \\ -1 & \text { if } x_{j}-x_{k}<0\end{cases}
$$

An upward (increasing) or downward (decreasing) trend can be expressed by a positive or negative value of $Z$. First the variance of $S$ is computed by the following equation (4) which takes into account that ties may be present:

$$
\operatorname{VAR}(S)=\frac{1}{18}\left[n(n-1)(2 n+5)-\sum_{p=1}^{q} t_{p}\left(t_{p}-1\right)\left(2 t_{p}+5\right)\right]
$$

where $q$ is the number of tied groups and $t_{p}$ is the number of data values in the $p$ th group.

The values of $S$ and $\operatorname{VAR}(S)$ are used to compute the test statistic $Z$ as follows:

$$
Z= \begin{cases}\frac{S-1}{\sqrt{V A R(S)}} & \text { if } S>0 \\ 0 & \text { if } S=0 \\ \frac{S+1}{\sqrt{V A R(S)}} & \text { if } S<0\end{cases}
$$

Then, the null hypothesis of no trend, $H_{0}$, is tested in order to accept or reject it. The $x_{i}$ observations are randomly ordered chronologically, contrary to the alternative hypothesis $H_{1}$, where there is an increasing or decreasing monotonic trend. The statistic test $Z$ (normal approximation) is computed because all time series are longer than ten. The statistic $Z$ has a normal distribution. The absolute value of $Z$ can be compared to the standard normal cumulative distribution to identify if there is a monotone trend or not at the specified level of significance.

\section{Results}

\subsection{Multiannual water level changes}

The trend analysis for all of the studied series of water levels in lakes showed high spatial and temporal variability. Trends in the series of mean monthly water levels from February to July are predominantly increasing, and from September to January-decreasing (Table 2). 


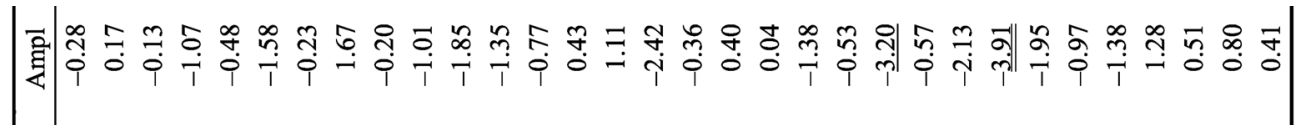

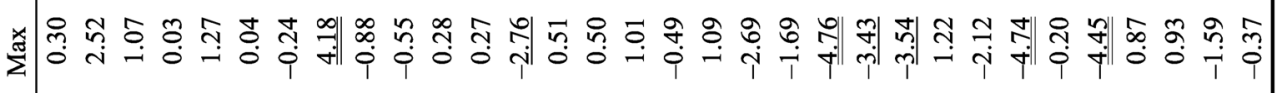

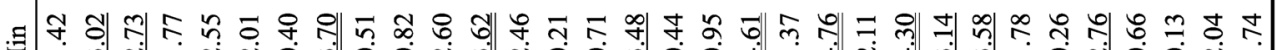

๘

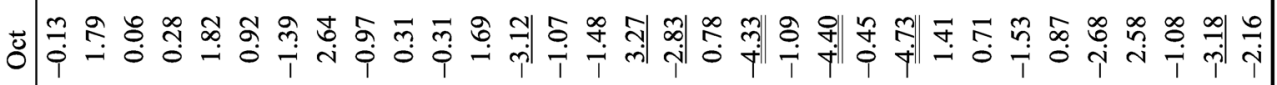

๑े|లి

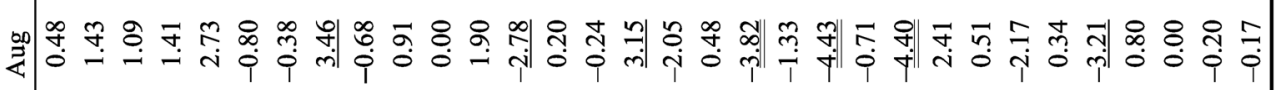

J

ำ

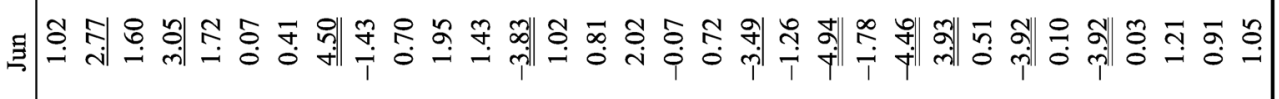

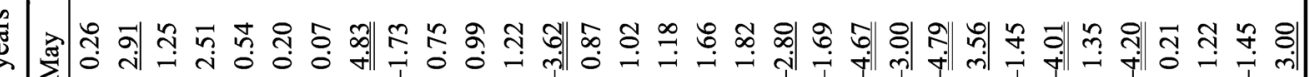

$\stackrel{0}{ \pm}$

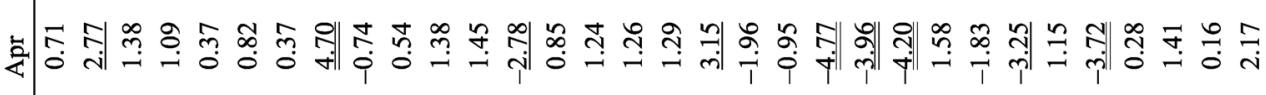

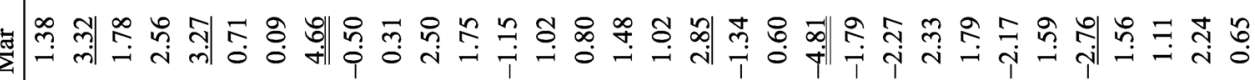

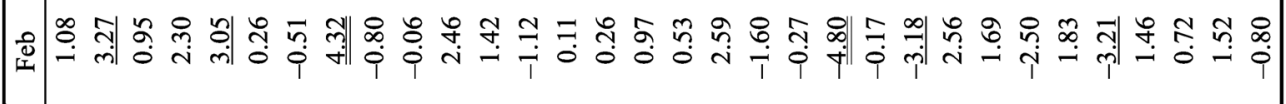

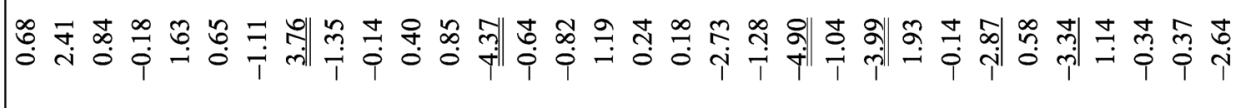

它 궁

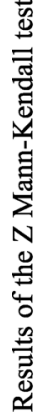

궁

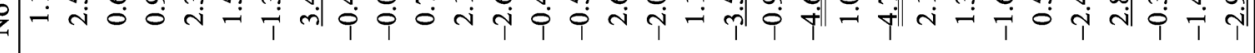

竎

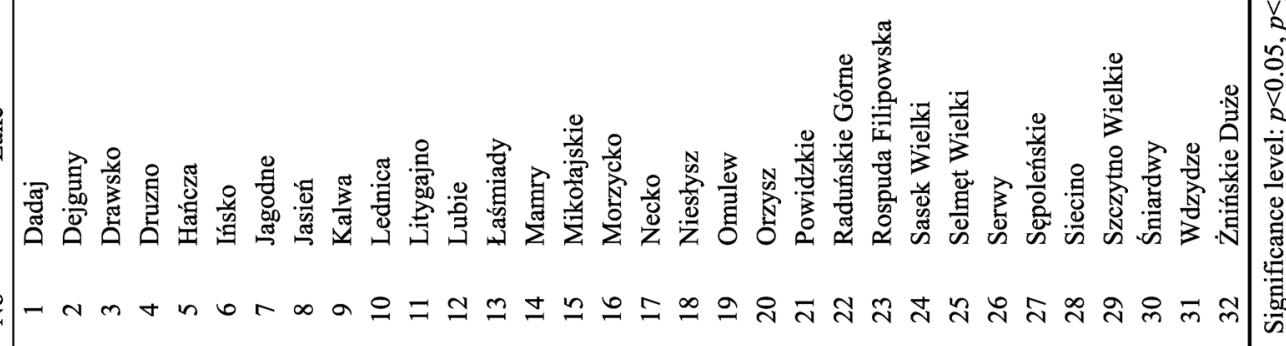


The number of lakes with series of water levels with statistically significant trends is varied. Statistically significant $(p<0.05)$ increasing trends were observed in series from 2 lakes (in the case of series of water levels for January) to 8 lakes (increasing trends in water levels in lakes in March). The strongest increasing trends $(p<0.001)$ are represented by series for two lakes: Lake Jasień (series of water levels from December to June) and Lake Sasek Wielki (series of water levels for June). Statistically significant $(p<0.05)$ negative trends were observed for 4 lakes in series of water levels in February and March, and for 8 lakes in series of water levels in October. The strongest decreasing trends $(p<0.001)$ were observed in the case of 7 lakes. In the case of Lake Powidzkie, this concerns all monthly series of water levels. Mean water levels for Lake Rospuda significantly decrease in the case of series from April to December, for Lake Omulew from July to October, for Lake Siecino from April to June, for Lake Serwy from May to June, and for Lake Laśmiady in January, May, and June. In the lakes mentioned above, similarly strong negative trends are also observed in series of mean annual water levels, as well as maximum and minimum annual water levels and mean seasonal water levels.

In the studied lakes, series of mean annual water levels for 18 lakes show increasing trends, and for 14 lakes decreasing trends. Statistically significant $(p<0.05)$ decreasing tendencies are observed in the case of 7 lakes, 3 of which show statistical significance of $p<0.001$. Statistically significant $(p<0.05)$ increasing trends are determined based on annual series of water levels in 6 lakes, including one lake with a trend significant at a level of $p<0.001$ (Table 2). Selected examples of the course of mean annual water levels in the analysed multiannual are presented in Figure 2.

Series of maximum and minimum annual water levels shows statistically significant $(p<0.05)$ increasing trends for series of minimum water levels for 9 lakes, including one at a level of $p<0.001$. Seven lakes show statistically significant decreasing trends in the series ( $p$ $<0.05)$, including three very significant ones $(p<0.001)$. In the case of series of maximum annual water levels, statistically significant trends are determined for only 2 lakes, and decreasing trends for as many as 8 (Table 2).

The analysis of trends in series of annual water level amplitudes shows the prevalence of decreasing trends, observed in 22 lakes. The trends, however, were statistically significant only in four cases $(p<0.05)$, namely in Lakes Morzycko, Raduńskie Górne, Sasek Wielki, and Selmęt Wielki, for which the significance of the decreasing trend is at a level of $p$ $<0.001$.

\subsection{Changes in trends in annual series of water stages}

Because the analysis showed high variability of both the direction and significance of trends in the studied series of water levels from the years 1976-2010, a more detailed analysis were performed regarding shorter 20-year observation terms of mean annual water levels in lakes. A total of sixteen 20-year terms were analysed with a temporal shift of 1 year, beginning from the period 1976-1995, and ending with the period 1991-2010. Figure 3 presents the correlation coefficients of linear regression for each of the 20 -year terms with threshold values at a significance level of $p=0.05$.

Five of the studied lakes showing statistically significant increasing trends in the years 1976-2010 are distinguished by considerable changes in the correlation coefficient in the 

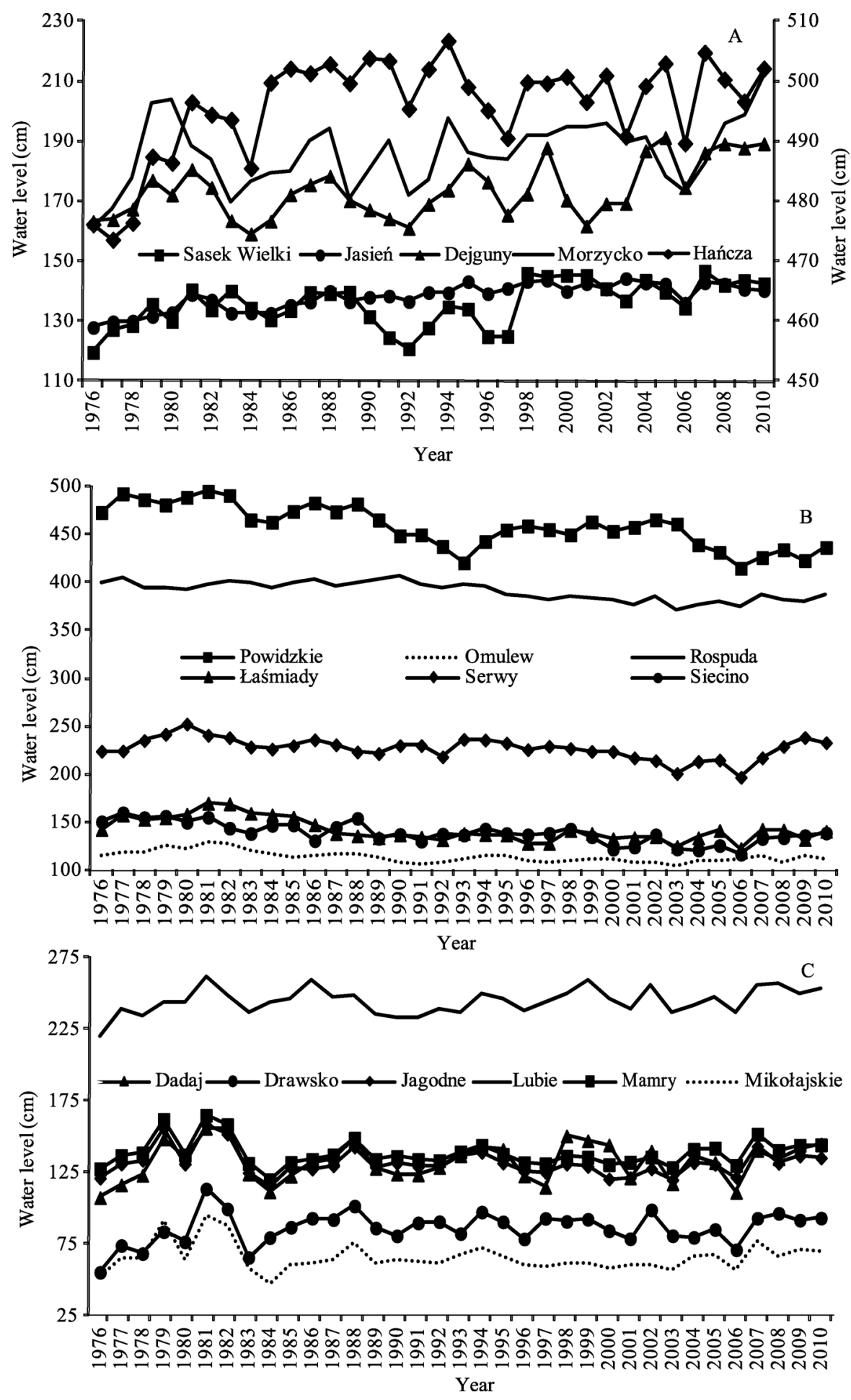

Figure 2 Multiannual course of mean annual water levels in selected lakes in the years 1976-2010

a. lakes with a significant increasing water level trend; b. lakes with a significant decreasing water level trend; c. lakes showing no significant water level trends 
analysed 20-year terms (Figure 3a). Only 2 lakes (Dejguny and Sasek Wielki) show a similar course of correlation coefficients, and reach statistically significant values only in series after 1988. In the case of Lake Morzycko, periods with significant correlation coefficients are 20-year terms from 1981-2000 to 1985-2004. The course of the correlation coefficient for Lake Hańcza shows that the highest values are obtained at the beginning of the studied multiannual 1976-1995. The correlation coefficient values in consecutive periods successively decrease. In the years 1985-2004 and 1987-2006, they are even negative and statistically significant. The most regular course and constant value is reached by correlation coefficients in the case of Lake Jasień, although in the last two 20-year terms after 1990, they are statistically insignificant.

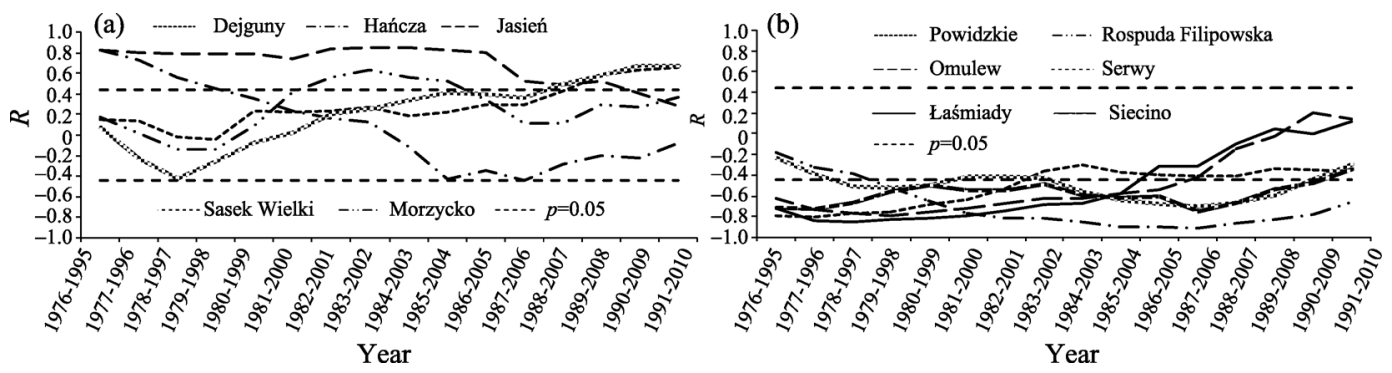

Figure 3 Changes in correlation coefficients of water levels in 20-year terms

a. lakes showing an increasing tendency; b. lakes showing a decreasing tendency

Lakes with (statistically significant) decreasing trends of annual water levels in the years 1976-2010 show less substantial changes of the correlation coefficient in the studied 20-year terms, and its value is usually statistically significant (Figure $3 \mathrm{~b}$ ). This pattern does not concern Lakes Łaśmiady and Omulew. Their respective series of annual water levels from 1986 and 1987 are distinguished by an increase in the correlation coefficient to positive, although statistically insignificant values.

The remaining lakes not showing statistically significant trends in the studied series of water stages are distinguished by a similar, characteristic, cyclical course of correlation coefficient curves. Correlation coefficients reach low values for series from the years 1978-1997 and 1987-2006, and high in the years: 1976-1995, 1983-2002, and 1991-2010 (Figure 4).

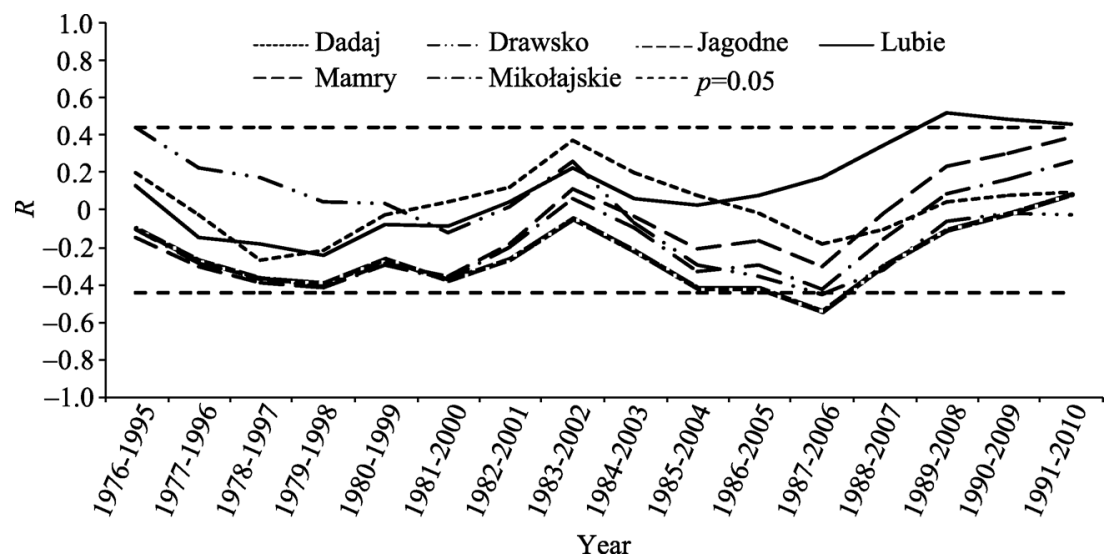

Figure 4 Changes in correlation coefficients of water levels in 20-year terms for selected lakes not showing statistically significant trends in annual water levels 


\subsection{Meteorological factors contributing to water-level changes}

The investigation of the effect of basic climate components determining the conditions of water supply to lakes on their water levels involved the analysis of tendencies in changes in precipitation and air temperature values at 9 meteorological stations, and their correlations with lake water levels.

The analysis of tendencies in monthly, seasonal, and annual sequences of precipitation showed a statistically significant increase in series for February (at 8 stations). In the case of seasonal precipitation, only series of spring precipitation at 3 stations (Chojnice, Łeba, and Poznań) showed a statistically significant increase, and for series of annual precipitation only at the station in Szczecin. The paper only includes results of the Z Mann-Kendall test for annual series of precipitation and air temperature (Table 3).

Table 3 Results of the Z Mann-Kendall test for annual precipitation totals and air temperatures in 1976-2010

\begin{tabular}{cccccccccc}
\hline Station & Chojnice & Koszalin & Łeba & Mikołajki & Poznań & Suwałki & Szczecin & Toruń & Zielona Góra \\
\hline $\begin{array}{c}\text { Precipitation } \\
\begin{array}{c}\text { Air } \\
\text { temperature }\end{array}\end{array}$ & $\underline{3.01}$ & 1.41 & 1.93 & 1.14 & 1.11 & 0.17 & 2.09 & 0.48 & 0.88 \\
\hline
\end{tabular}

Significance level: $p<0.05, p<\underline{0.01,} p<\underline{\underline{0.001}}$

Increasing tendencies of air temperatures are considerably stronger. At the majority of stations, a very statistically significant $(p<0.001)$ increase in air temperatures is observed in April, July, and August. Among seasonal temperatures, the highest temperature increase is observed in summer, but a statistically significant increase in temperatures $(p<0.05)$ also occurs at the majority of stations in spring. In series of mean annual air temperatures, a statistically significant increase $(p<0.05)$ was observed at all of the stations except for Szczecin.

The determination of the effect of meteorological conditions on water level changes in lakes involved the analysis of correlations of synchronic and asynchronic (with a temporal shift of one year) series of water levels in lakes with precipitation and air temperature. The correlations of lake water levels with precipitation amounts are positive, and in the case of 13 lakes they proved statistically significant $(p<0.05)$, in the case of 5 lakes even at a level of $p<0.001$ (Table 4 and Figure 5). The weakest correlations were recorded in the case of lakes with the strongest water level trends resulting from local conditions.

The study also confirmed that in the case of many lakes, even stronger correlations occur between precipitation and annual water levels observed in the following year (Table 4 and Figure 5b). This fact was emphasised by among others Vincent et al. (1979) and Chojnowski (1995). As many as 19 lakes show statistically significant correlations of water levels with the precipitation amount observed in the preceding year, including 12 lakes with the significance at a level of $p<0.001$.

The second meteorological factor determining the water balance of lakes and their water levels is air temperature. An increase in air temperature results in an increase in evaporation, and a decrease in the water level. Therefore, the majority of lakes show negative correlations with air temperature. The correlations, however, are statistically significant only in the case of 4 lakes $(p<0.05)$-Table 4 and Figure 6a. Due to the observed tendencies of an increase in air temperatures, in the case of lakes where water stages also increase, positive correlations 
are obtained (Lakes Druzno, Jasień, Hańcza, and Sasek Wielki). In the case of 12 lakes, even stronger negative correlations are observed between annual water levels and the mean temperature observed in the preceding year (Table 4 and Figure 6b). Four lakes (Omulew, Powidzkie, Siecino, and Żnińskie Duże) show statistically significant correlations even at a level of $\mathrm{p}<0.001$. The majority of them, however, are lakes with annual water levels showing a decreasing tendency resulting from human activity.

Table 4 Coefficients of correlation of water stages in lakes with precipitation amount and air temperature

\begin{tabular}{|c|c|c|c|c|c|c|}
\hline \multirow{2}{*}{ No } & \multirow{2}{*}{ Lake } & \multirow{2}{*}{$\begin{array}{l}\text { Meteorological } \\
\text { station }\end{array}$} & \multicolumn{4}{|c|}{ Lake level } \\
\hline & & & Precipitation & $\begin{array}{l}\text { Precipitation } \\
-1 \text { year }\end{array}$ & Air temperature & $\begin{array}{c}\text { Air temperature } \\
-1 \text { year }\end{array}$ \\
\hline 1 & Dadaj & Mikołajki & 0.224 & $\underline{0.443}$ & 0.158 & -0.246 \\
\hline 2 & Dejguny & Mikołajki & $\underline{0.359}$ & $\underline{0.528}$ & 0.104 & -0.026 \\
\hline 3 & Drawsko & Koszalin & 0.323 & $\underline{0.511}$ & 0.232 & -0.163 \\
\hline 4 & Druzno & Łeba & 0.243 & 0.144 & $\underline{0.469}$ & 0.092 \\
\hline 5 & Hańcza & Suwałki & 0.160 & 0.152 & 0.384 & 0.215 \\
\hline 6 & Ińsko & Szczecin & 0.308 & $\underline{0.483}$ & 0.195 & -0.096 \\
\hline 7 & Jagodne & Mikołajki & 0.154 & 0.414 & -0.054 & $-\underline{0.379}$ \\
\hline 8 & Jasień & Leba & 0.388 & 0.411 & $\underline{0.494}$ & 0.393 \\
\hline 9 & Kalwa & Mikołajki & 0.353 & $\underline{0.460}$ & -0.053 & $-\underline{0.420}$ \\
\hline 10 & Lednica & Poznań & 0.410 & $\underline{\underline{0.583}}$ & -0.024 & -0.275 \\
\hline 11 & Litygajno & Mikołajki & 0.351 & $\underline{\underline{0.541}}$ & 0.106 & -0.248 \\
\hline 12 & Lubie & Szczecin & $\underline{0.447}$ & 0.397 & 0.100 & -0.316 \\
\hline 13 & Łaśmiady & Suwałki & 0.312 & 0.193 & -0.309 & $-\underline{0.411}$ \\
\hline 14 & Mamry & Mikołajki & 0.186 & $\underline{0.470}$ & -0.005 & $-\underline{0.364}$ \\
\hline 15 & Mikołajskie & Mikołajki & 0.154 & $\underline{0.434}$ & -0.041 & $-\underline{0.372}$ \\
\hline 16 & Morzycko & Szczecin & 0.402 & $\underline{0.505}$ & -0.060 & -0.012 \\
\hline 17 & Necko & Suwałki & 0.263 & 0.273 & 0.096 & -0.056 \\
\hline 18 & Niesłysz & Zielona Góra & $\underline{\underline{0.564}}$ & 0.413 & -0.124 & -0.250 \\
\hline 19 & Omulew & Mikołajki & 0.189 & 0.196 & $-\underline{0.350}$ & $-\underline{\underline{0.559}}$ \\
\hline 20 & Orzysz & Mikołajki & 0.124 & $\underline{0.452}$ & -0.103 & $-\underline{0.410}$ \\
\hline 21 & Powidzkie & Poznań & -0.065 & 0.191 & $-\underline{0.499}$ & $-\underline{\underline{0.583}}$ \\
\hline 22 & Raduńskie Górne & Łeba & -0.103 & 0.053 & 0.096 & -0.198 \\
\hline 23 & Rospuda Filipowska & Suwałki & 0.087 & 0.029 & -0.203 & $-\underline{0.388}$ \\
\hline 24 & Sasek Wielki & Mikołajki & 0.350 & 0.351 & $\underline{0.430}$ & 0.089 \\
\hline 25 & Selmęt Wielki & Suwałki & $\underline{0.457}$ & 0.246 & -0.093 & -0.294 \\
\hline 26 & Serwy & Suwałki & 0.192 & 0.199 & -0.313 & $-\underline{0.340}$ \\
\hline 27 & Sępoleńskie & Chojnice & $\underline{\underline{0.548}}$ & 0.262 & -0.083 & -0.152 \\
\hline 28 & Siecino & Koszalin & 0.004 & -0.030 & $-\underline{0.420}$ & $-\underline{\underline{0.534}}$ \\
\hline 29 & Szczytno Wielkie & Chojnice & 0.189 & $\underline{0.510}$ & 0.330 & -0.044 \\
\hline 30 & Śniardwy & Mikołajki & 0.140 & 0.426 & 0.005 & -0.310 \\
\hline 31 & Wdzydze & Chojnice & 0.346 & -0.027 & 0.085 & -0.129 \\
\hline 32 & Żnińskie Duże & Toruń & $\underline{0.465}$ & 0.366 & $-\underline{0.410}$ & $-\underline{0.523}$ \\
\hline
\end{tabular}

Significance level: $p<0.05, p<\underline{0.01,} p<\underline{\underline{0.001}}$ 
The analysed multiannual 1976-2010 included 3 periods of draught (in the years: 1982-1983; 1989-1992; and 2003). The strongest draught with the largest range occurred in 1992 (Łabędzki, 2004).

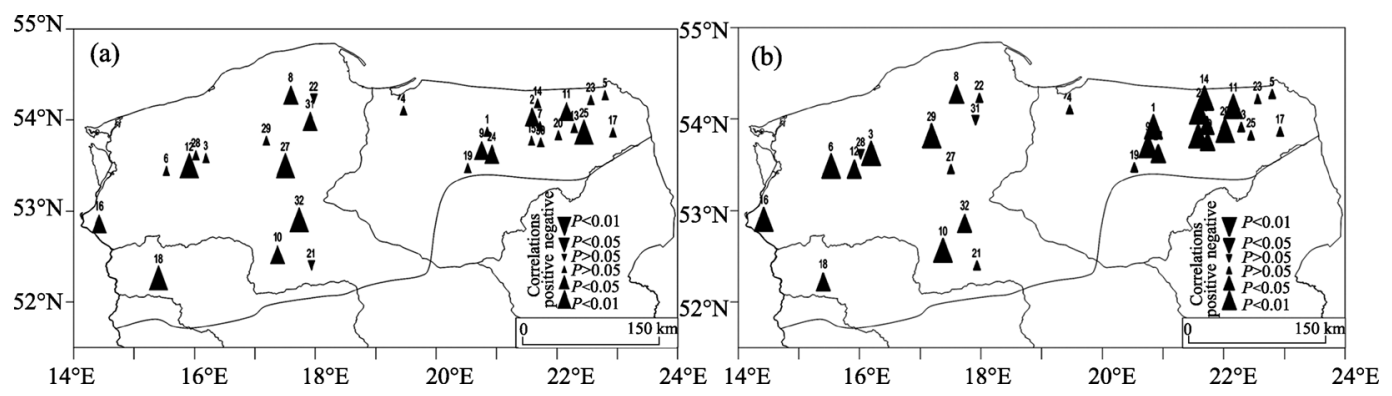

Figure 5 Statistical significance of coefficients of correlation of mean annual water levels in lakes with the annual precipitation total

a. synchronic series; b. asynchronic series

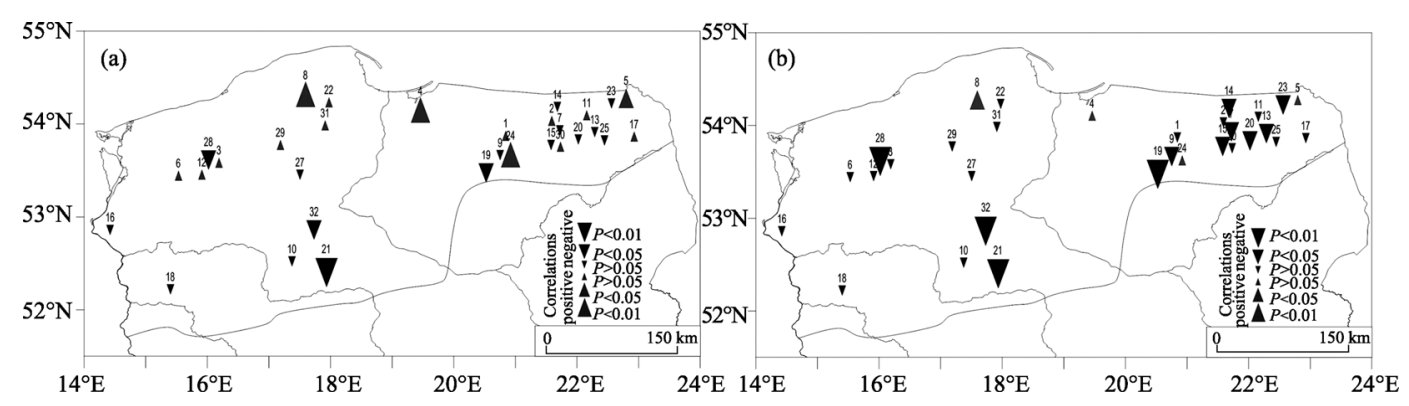

Figure 6 Statistical significance of coefficients of correlation between mean annual water levels in lakes and mean annual air temperature

a. synchronic series; b. asynchronic series

Very low water levels were usually observed in the lakes in these periods, particularly when higher air temperatures were recorded in the same year, e.g. in 1989 and 1992. In some of the lakes, the response of the water level to low water supply from precipitation is delayed. This may be caused by smaller losses to evaporation, observed at lower air temperatures, e.g. in 1996 - Lake Dadaj (Figure 7).

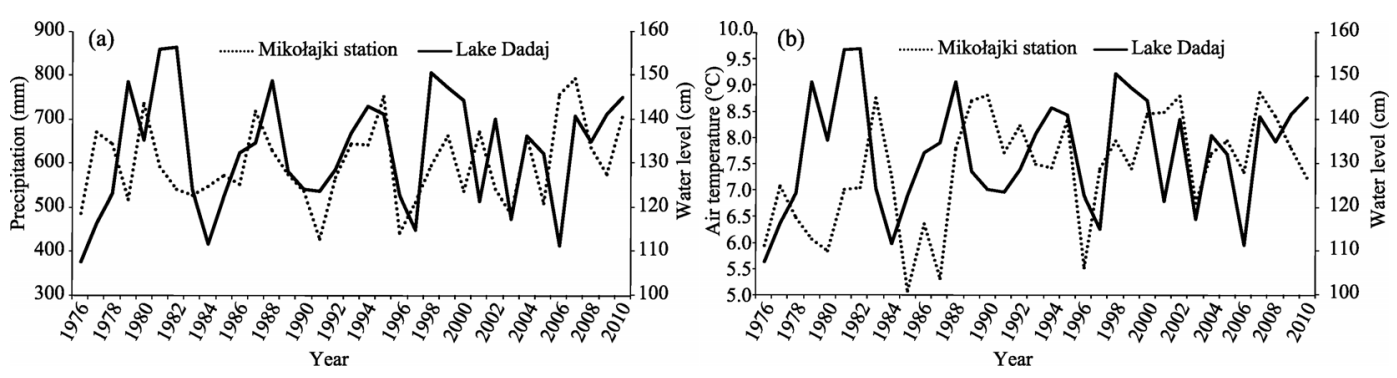

Figure 7 Course of water levels in Lake Dadaj and atmospheric precipitation (a) and air temperature (b) at Mikołajki station in 1976-2010

Responses of lakes are also varied in the case of higher precipitation, when high water supply and low losses to evaporation are observed, and high water levels occur in the fol- 
lowing year, e.g. in 1980, 1987, and 2006. When higher precipitation supply is accompanied by high losses to evaporation (high temperature), a high water level in lakes is frequently observed in the same year, e.g. in 1995 and 1999.

\section{Discussion}

The course of water level changes in the analysed lakes suggests a complex character of the process. This fact is reflected in the broad range of tendencies in water level changes. Such a situation is caused by a combination of co-occurring features and factors: meteorological (precipitation, evaporation), individual parameters of lakes (their morphometry and relations with the catchment), and anthropopressure (melioration works, water intake). Their effect on water level changes is emphasised by among others Fathian et al. (2014) based on the example of Lake Urmia (North-western Iran). According to the authors, the observed decreasing tendencies in the lake may be determined by an increase in air temperature, variable precipitation, and intensified human activity.

Shortage of precipitation is one of the potential reasons for a decrease in water levels in lakes. Lack of precipitation or its shortage itself does not result in a decrease in the water level, if it occurs in the season in which the alimentation of lakes from precipitation is not necessary, e.g. due to high retention levels of the catchment, or because it is not the regular lake alimentation season. Shortage or lack of precipitation may trigger a decrease in water levels in lakes, usually when it occurs in the season of lake alimentation with precipitation waters and at high air temperature. The combined effect of two climatic factors, namely atmospheric draught and high temperature disturbs catchment alimentation and causes intensive evaporation of water contained in the soil and surface water bodies. A further decrease in water levels depends only on whether and to what degree the water resources in the lake itself and its catchment can be supplemented. If autumn rainfall is scarce, winter is snowless, and spring meltwater season early, such a combination of conditions does not guarantee the reconstruction of the water resources of the catchment. In such a situation, the water table in a lake at the beginning of a new vegetation season is at a level only slightly higher than in preceding autumn. If the conditions in the new hydrological year are similar as in the preceding one (low precipitation, high temperature), or precipitation even if higher is insufficient, the tendency for decreasing water levels as a result of weak alimentation of lakes may continue. The meteorological conditions of water level changes are therefore strongly varied. An increase in water supply is not always accompanied by higher water levels, and a decrease in water supply by lower water levels. This may result from the effect of air temperature determining higher or lower losses to evaporation. As a consequence, water level changes and precipitation amounts may be synchronic or shifted by one year. Such patterns are particularly clearly observed in lakes with a quasi-natural regime of water levels. Modifications of the observed correlations result from thermal conditions, and their strength from the individual features of the lake and its catchment.

In the case of Polish lakes, human activity is mentioned by Górniak and Piekarski (2002) as important in modifying the natural hydrological cycle in lakes. Dynamic social development in Poland was recorded in the 18th and 19th centuries. During the time, extensive melioration works were conducted, and the obtained areas were adapted for agricultural or 
settlement purposes. A number of lakes were subject to a considerable water level decrease (Kaniecki, 1991, Kowalewski, 2012) or complete disappearance (Ptak et al., 2013). Over the next decades, the situation regarding water resources in Poland changed radically. Considerable water deficits are currently recorded (particularly in the central part of the country). The water resources of Poland are among the lowest in Europe (Kowalczak et al., 1997), and are comparable to desert countries such as Egypt. The necessity to retain water in catchments in order to reduce extreme hydrological situations (both draughts and floods) has become a priority. In reference to lakes, the direct interference in their hydrological regime concerns among others hydrotechnical development on the outflow, permitting regulation of water levels, and therefore of the accumulated water resources. For example, only in the case of the Wielkopolskie Province, damming of 48 natural lakes with a total area of 3023 ha and volume of 33.008 million $\mathrm{m}^{3}$ is stipulated (www.wzmiuw.pl).

Results obtained for the analysed multiannual suggest the prevalence of the increasing tendency of water levels (recorded for a total of 22 lakes with varied degrees of significance). A similar situation, i.e. prevalence of water level increase in a given group of lakes, was observed in Poland by among others Dąbrowski (2004), where increase was recorded for 16 out of 24 lakes. Other papers (Skibniewski, 1954; Pasławski, 1973; Chojnowski, 1992) record a decrease in water levels in the majority of the analysed cases. In such a situation, it is difficult to synthetically refer the obtained data to earlier papers. In addition to a different time period, they also concern a different number of lakes. This fact, however, proves a certain cyclical character of water level changes in lakes, as confirmed by the analysis of the multiannual 1976-2010 presented in the paper, showing variable character in division into shorter periods. The extrapolation of the obtained data to lakes in other regions of the world is equally complicated. Although the mechanism of water level changes is basically the same, the climatic and morphometric conditions of lakes, and particularly the direction and scale of human activities, can be extremely varied. The territory of Germany, neighbouring to the west, is similar to the study area in a number of aspects. The analysis of water level changes in lakes in the Mecklenburg Lake District by Kaiser et al. (2014) showed that in the years 1999-2008, the majority of them showed a decrease in the water level (23 out of 45 studied lakes), no tendencies of changes were recorded for 15 lakes, and an increase in water level was recorded in seven cases.

Based on a literature review, Bajkiewicz-Grabowska (2001) emphasised that the course of water levels in Polish lakes in the multiannual aspect is primarily determined by local and not climatic conditions. The author confirmed this by analysing 21 lakes from north-eastern Poland in the years 1951-1998. She recorded no statistically significant correlations between precipitation and water levels in the lakes. Determining correlations between water levels and precipitation for 17 lakes located in the catchment area of the Odra River, Kowalik et al. (2008) recorded statistical significance in only two cases. In the multiannual analysed in the paper, such a correlation was observed for 5 lakes. Only 2 lakes (out of 32) showed no positive correlation with precipitation (Lakes Powidzkie and Raduńskie Górne). They are both under strong impact of human activity. Lake Powidzkie is distinguished by the highest decrease in water level $\left(-17.2 \mathrm{~cm} \cdot \mathrm{dec}^{-1}\right)$ among all of the lakes. The situation is caused by a disturbance of the groundwater regime over an extensive area as a result of the activity of the nearby brown coal mine. According to Przybyłek and Nowak (2011), mining 
meliorations caused the development of a depression cone which strongly affected the groundwater supply to Lake Powidzkie (and other lakes in the sequence of the PowidzkieOstrowskie channel). This unfavourable situation is not even likely to be reduced by means of the hydrotechnical infrastructure (weir) established on the outflow from Lake Powidzkie. The variability of water levels in Lake Powidzkie and the lake nearest to it (approximately $40 \mathrm{~km}$ ), namely Lake Lednica in relation to precipitation for Poznań station is presented in Figure 8 .

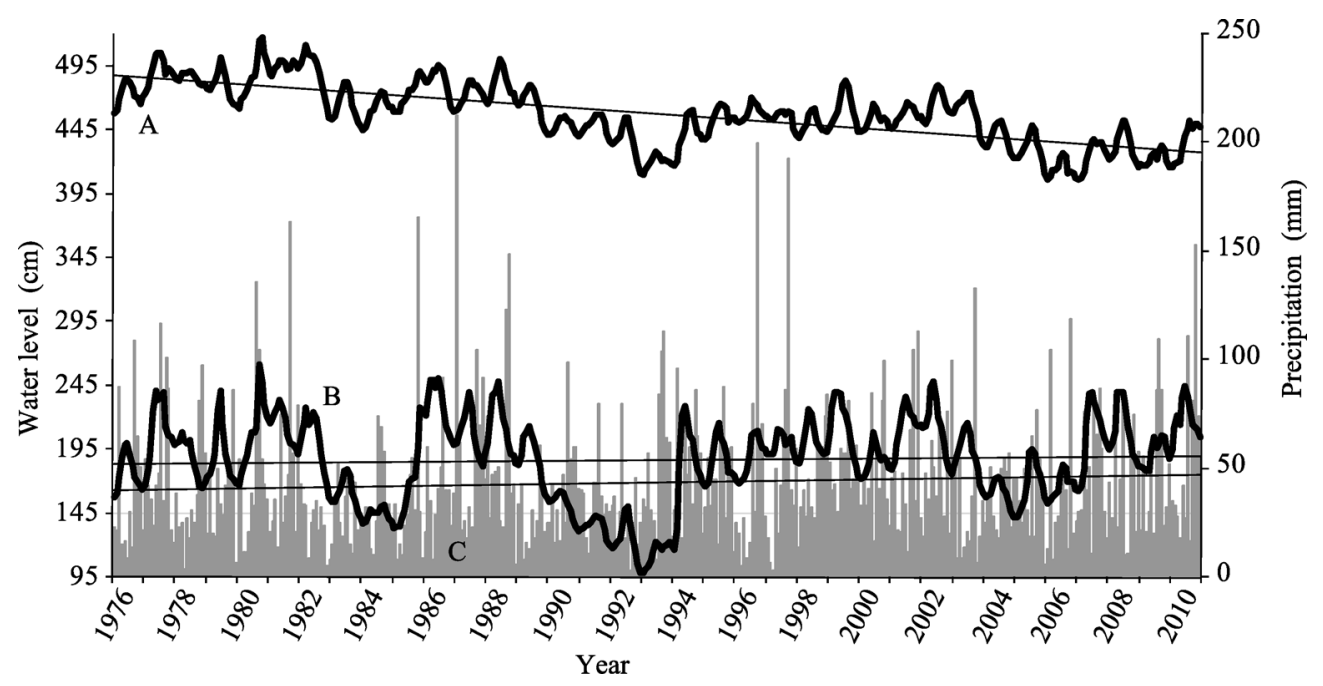

Figure 8 Course of monthly water levels in selected lakes and precipitation in the years 1976-2010 A. Lake Powidzkie; B. Lake Lednica; C. Poznań meteorological station

Lake Raduńskie Górne, included in a larger group of lakes (Raduńskie-Otrzyckie), is important for the economic development of the region. According to Okulanis (1981), who performed a detailed study of the lake, owing to the possibility to artificially regulate discharge, the entire group of the above mentioned lakes constitutes a natural retention reservoir contributing to even discharges of the Radunia River which flows through it. This fact is of importance for the functioning of hydro power plants located on the river (a total of eight power plants with power of $14 \mathrm{MW}$ ) as well as other economic infrastructure (e.g. sawmills) located between lakes. In reference to the variability of water levels, the same author determines that the use of lakes for the aforementioned purposes caused a disturbance in the dynamic balance, and the course of changes is of local character. The artificial transformation of the water level regime of Lake Raduńskie Górne resulting from the functioning of the hydro power plant, although considerably varying from other analysed lakes, does not show such an extreme course as a different lake in Poland adapted for energy production. Lake Żarnowieckie (1431 ha) was assumed to serve as a water reservoir for the purposes of a nuclear power plant which was never built. Currently, its southern shore is occupied by a pumping power station (800 MW). Due to this, considerable daily water level changes are observed (approximately $1 \mathrm{~m}$ ). Based on their observation, Kaźmierski and Jasińska (1996) determined that extreme water stages recorded before the launch of the pump power station in 1983 were exceeded almost every day.

The remaining 25 lakes showing a positive (but statistically insignificant) correlation be- 
tween water levels and precipitation suggest the predominant role of local factors - blurring the direct correlation between precipitation and water levels. The adaptation of lakes to agricultural purposes is quite a common form of water level regulation (Coe and Foley, 2001, Legesse and Ayenew, 2006, Yildirim et al., 2011). In extreme cases, poorly planned water management in reference to a given lake may result in an irreversible decrease in water level, and as a consequence its disappearance. The most spectacular example of such a situation is Lake Aralskie which was completely dried as a result of irrigation works (Shi et al., 2014, Zmijewski and Becker, 2014). Among the analysed lakes, such activity can be illustrated among others based on the example of Lake Wdzydze, used for irrigation of the nearby meadows. Churski (1961) describes the entire cycle in detail. In the spring season (March-April), irrigation of meadows occurs. During this time, the water level rapidly decreases (by $1 \mathrm{~m}$ ). At the turn of June and July, the weir regulating the water level is closed (due to haymaking). This is followed by further irrigation of meadows. The weir is closed again in September, when the water level increases by $2 \mathrm{~m}$. After the completion of the second hay harvest, the water level decreases to the average level, and such a situation is maintained throughout winter.

Other examples of water level regulation are encountered in lakes adapted to navigation purposes, e.g. Lakes Necko and Serwy. The former lake is located on the Augustów Canal. The latter, due to the weir regulation, constitutes the primary water reservoir for the summit level of the canal.

The hydrotechnical development on lakes can change its function depending on the character of the prevalent human activity. Murat-Błażejewska et al. (2008) describe the case of Lake Niepruszewskie (242 ha), where the existing weir was used for agricultural irrigations in the first period after its construction (1200 ha), and then was used for the purposes of fisheries. In the recent period, as a result of pressure of owners of land surrounding the lake, its functioning involving increasing retention was reduced.

The depth of lakes and their geological conditions constitute another issue. The location of the lake in efficient aquifers may determine the character and course of the occurring processes (Choiński and Ptak, 2012). In such situations, the course of precipitation does not have to reflect the course of water levels. This fact is confirmed in the case of Lake Jasien (with the highest increase in mean annual water levels among all of the lakes, amounting to $3.8 \mathrm{~cm} \cdot \mathrm{dec}^{-1}$ ), where no significant correlation with precipitation was recorded (although the correlation was positive). According to Borowiak (2000), in this case, surface inflow constitutes a secondary component of water supply, and groundwater alimentation does not only include local aquifers, but exceeds the boundaries of the topographic catchment.

The global increase in air temperature is reflected in the increase of lake waters (Wilhelm and Adrian, 2008, Schmid et al., 2014, Wrzesiński et al., 2015). This translates to an increase in evaporation from water surface. Analysing evaporation from the water surface of Lake Sławskie in the period from May to October 2007, Chmal (2008) recorded its highest value in June, amounting to $114.3 \mathrm{~mm}$. At the multiannual scale, considerable changes in the course of the process are observed for Poland. Kędziora (2010) estimates that in the years 1996-2006, evaporation from water surface for the Wielkopolskie Province increased from 600 to $1000 \mathrm{~mm}$.

Only three of all of the discussed lakes show positive correlations with air temperature. 
This is a contradiction from the point of view of (undisturbed) water balance. This situation should be interpreted similarly as in the case of precipitation, where the key determinants of water level changes are individual features and local conditions of a given lake. Lake Druzno is an interesting case, where components influencing water level changes include both human activity and natural factors (but not meteorological). According to Fac-Beneda (2013), the main causes include water discharges (by means of pumping stations and discharge pipes) from local polders and water level changes in the Vistula Lagoon (a bay of the Baltic Sea) with which Lake Druzno shares a hydraulic network through the Elblagg River. A similar correlation is described by Zolár and Bengtsson (2006) based on the example of Lake Poopó in Bolivia, where water levels particularly depend on the water levels in Lake Tititaca (connected with Lake Poopó with the Desaguadero River).

\section{Conclusions}

The analysis of water level changes in Poland presented in this paper suggests the complex character of the issue.

(1) The analysis of mean annual water levels from the multiannual 1976-2010 suggested the prevalence of increasing trends (for 18 lakes, including 6 statistically significant ones). Out of the remaining 14 lakes with decreasing trends, the correlation was statistically significant for 7 lakes. The study also showed that tendencies of air temperature changes are more statistically significant than those of atmospheric precipitation. Spring, summer, and annual temperature series showed statistically significant increasing trends. The amount of atmospheric precipitation as a revenue value in the water balance should be of key importance in water level changes in lakes. As evidenced in the study, due to the local conditions (morphometric parameters of lakes, their management, etc.), this pattern is ambiguous. Although water levels in 30 (out of 32) lakes showed positive correlations with annual precipitation totals, only five cases were statistically significant. Water levels in lakes show weaker correlations with air temperature. Statistically significant correlations were only determined in the case of 3 lakes. According to the study, for the majority of lakes, their water levels are stronger correlated with asynchronic (shift by 1 year) than synchronic atmospheric precipitation and air temperature series. Correlations of air temperature with water level in the following year are usually negative, and in the case of 12 lakes, statistically significant.

(2) Several centuries of human activity had the strongest impact on hydrological relations in Poland in this respect. At the first stage, it was related to meliorations (aimed at obtaining new land for agricultural and settlement purposes). Over the recent decades (due to the increasing water deficits in Poland), it was involved in the development of hydrotechnical infrastructure aimed at increased retention (of both surface and groundwaters). As evidenced by the analysed examples, in the case of lakes, the interference was both intended and unexpected. In the first case, the interference resulting from precisely controlled water management is aimed at meeting specific economic objectives, e.g. irrigation of the agricultural land in the area (e.g. Lake Wdzydze). In the second case, exploitation of brown coal by means of opencast method resulted in a considerable transformation of a number of components of the natural environment, including a disturbance in hydrogeological relations leading to successive lowering of the water level in Lake Powidzkie. 
(3) Due to the large group of factors co-determining water level changes, the process cannot be considered in the regional aspect. As evidenced by the selected examples, the possibility of identification of the primary determinants of water level changes requires individual analysis of each lake. Determining patterns is possible based on multiannual field research. Such an approach referring to individual lakes (de facto constituting study cases) is commonly applied and accepted in the world, as confirmed in the related literature.

\section{References}

Bajkiewicz-Grabowska E, 2001. Trends in water level changes in the lakes of north-eastern Poland. Limnological Review, 1: 3-14.

Borowiak D, 2000. Water regimes and hydrological functions of lakes of Polish Lowland. Seria: Badania Limnologiczne, 2, Wyd. KLUG, Gdańsk. (in Polish)

Castañeda C, Javier Gracia F, Luna E et al., 2015. Edaphic and geomorphic evidences of water level fluctuations in Gallocanta Lake, NE Spain. Geoderma, 239/240: 265-279.

Chlost I, Cieśliński R. 2005. Change of level of waters Lake Lebsko. Limnological Review, 5(1): 17-26.

Chojnowski S, 1992. Did draught also affect lakes? Gazeta Obserwatora IMGW, 4-6: 7-11. (in Polish)

Choiński A, Ptak M, 2012. Variation in the ice cover thickness on Lake Samołęskie as a result of underground water supply. Limnological Review, 3: 133-138.

Churski Z, 1961. Morphology and hydrography of the complex of Lake Wdzydze - Roczniki Nauk Rolniczych, 93D: 17-59. (in Polish)

Dąbrowski M, 2004. Trends in changes of lake water levels in the Pomerania Lakeland. Limnological Review, 4: 75-80.

Chmal M, 2008. Methods of evaporation measurements from free water surface at meteorological station in Radzyn. Wiadomości Meteorologii, Hydrologii, Gospodarki Wodnej, 2(3/4): 69-78. (in Polish)

Coe M T, Foley J A, 2001. Human and natural impacts on the water resources of the Lake Chad basin. Journal of Geophysical Research: Atmospheres, 106(D4): 3349-3356.

Duo B, Bianbaciren, Li L et al., 2009. The response of lake change to climate fluctuation in north Qinghai-Tibet Plateau in last 30 years. Journal of Geographical Sciences, 19(2): 131-142.

Dusini D S, Foster D L, Shore J A et al., 2009. The effect of Lake Erie water level variations on sediment resuspension. Journal of Great Lakes Research, 35(1): 1-12.

Hayashi M, van der Kamp G, 2007. Water level changes in ponds and lakes: The hydrological processes. Plant Disturbance Ecology, 311-339.

Fac-Beneda J, 2013. The hydrological characteristics of Lake Druzno. In: Lake Druzno Natural Monograph (ed.). Cz. Nitecki, Monografia Przyrodnicza. Wyd. Mantis, Olsztyn, 15-31. (in Polish)

Fathian F, Dehghan Z, Eslamian S, 2014. Analysis of water level changes in Lake Urmia based on data characteristics and non-parametric test. International Journal of Hydrology Science and Technology, 4(1): 18-38.

Górniak A, Piekarski K, 2002. Seasonal and multiannual changes of water levels in lakes of northeastern Poland. Polish Journal of Environmental Studies, 11(4): 349-354.

Jańczak J, Choiński A, 1988. Water level fluctuations in selected lakes in Poland in the years 1956-1985. In: Natural and anthropogenic Transformations of Lakes and Wetlands in Poland, (red. Z. Churski), UMK, Toruń. (in Polish)

Kaiser K, Koch P J, Mauersberger R et al., 2014. Detection and attribution of lake-level dynamics in north-eastern central Europe in recent decades. Regional Environmental Change, 14(4): 1587-1600.

Kaniecki A, 1991. Problems of Wielkopolska Lowland drainage over the last 200 years and changes in its water conditions, Materiały konferencji, "Ochrona i racjonalne wykorzystanie zasobów wodnych na obszarach rolniczych w regionie Wielkopolski”, Akademia Rolnicza, Poznań. (in Polish)

Kaźmierski J, Jasińska E, 1996. Dynamics and thermal activity of lake waters. in: Majewski W (ed.). The State of 
the Żarnowieckie Lake after 10 Years of Water Power Station Exploitation). Warszawa: Oficyna Monografie Komitetu Gospodarki Wodnej Polskiej Akademii Nauk, Zeszyt, 11: 21-53. (in Polish)

Kędziora A, 2010. Climate changes and their effect on the water conditions of the agricultural landscape. In: Koźmiński C Z, Michalska B, Leśny J et al. Climatic Threats to Agriculture in Poland. (in Polish)

Kowalczak P, Farat R, Kepińska-Kasprzak M et al., 1997. Hierarchy of regional requirements of small scale retentio in Poland, Materiały badawcze, Seria: Gospodarka Wodna o Ochrona Wód, 19, Warszawa, IMGW. (in Polish)

Kowalewski G, 2012. Over 200 years of drainage practices and lake level drawdown in the Uściwierskie Lowering (Łęczna-Włodawa Lakeland). Limnological Review, 12(4): 179-190.

Konatowska M, Rutkowski P, 2008. The changes of the area and of the water-level of Kamińsko Lake (Zielonka Experimental Forestry Division) in the period of recent 150 years. Studia i Materiały Centrum Edukacji Przyrodniczo-Leśnej, 2(18): 205-217. (in Polish)

Kowalik A, Grześkowiak A, Nowak B, 2008. Lake's reaction to extreme changes in their supply. Wiadomości Meteorologii, Hydrologii, Gospodarki Wodnej, 2(3/4): 49-67. (in Polish)

Kutyła S, 2014. Characteristics of water level fluctuations in Polish lakes: A review of the literature. Environmental Protection and Natural Resources, 25(3): 27-34.

Legesse D, Ayenew T, 2006. Effect of improper water and land resource utilization on the central Main Ethiopian Rift lakes. Quaternary International, 148(1): 8-18.

Li X-Y, Xu H-Y, Sun Y-L et al., 2007. Lake-level change and water balance analysis at lake Qinghai, West China during recent decades. Water Resources Management, 21(9): 1505-1516.

Łabędzki L, 2004. Drought problems in Poland. Woda-Środowisko-Obszary Wiejskie, 1(10): 47-66. (in Polish)

Machowski R, Ruman M, Rzętała M, 2005. Water stage fluctuations in selected anthropogenic water reservoirs in the upper part of the Odra catchment. Limnological Review, 5: 145-153.

Michalczyk Z, Chmiel S, Turczyński M, 2011. Lake water stage dynamics in the Lęczna-Włodawa Lake District in 1991-2010. Limnological Review, 11(3): 113-122.

Micklin P P, 1988. Desiccation of the Aral Sea: A water management disaster in the Soviet Union. Science, 241: 1170-1176.

Murat-Błażejewska S, Zbierska J, Ławniczak A et al., 2008. Exploitation of water infrastructure in aspect of water resources lowland river catchment. Acta Scientiarum Polonorum Architectura, 7(2): 13-22. (in Polish)

Niewiarowski W, 1978. Fluctuations of water-level in the Gopło Lake and their reasons. Polish Archives of Hydrobiology, 25: 301-306.

Nishihiro J, 2011. Effects of lake water-level control on lakeshore plant regeneration. Japanese Journal of Conservation Ecology, 16(2): 139-148.

Okulanis E, 1981. Limnological Study of the Lakes Raduńsko-Ostrzyckie. GTN: Gdańsk, Zakład Narodowy im. Ossolińskich: Wrocław, 108. (in Polish)

Pasławski Z, 1972. Multiannual water level fluctuations and tendencies in outflow lakes in northern Poland. Przegląd Geofizyczny, 17: 249-259. (in Polish)

Pasławski Z, 1973. Long-term fluctuations and trends in water level changes in the outflow lakes in northern Poland. Hydrological Sciences Bulletin, 18(3): 295-301.

Piasecki A, Marszelewski W, 2014. Dynamics and consequences of water level fluctuations of selected lakes in the catchment of the Ostrowo-Gopło Channel. Limnological Review, 14(4): 187-194.

Polderman N J, Pryor S C, 2004. Linking synoptic-scale climate phenomena to lake-level variability in the Lake Michigan-Huron basin. Journal of Great Lakes Research, 30(3): 419-434.

Przybyłek J, Nowak B, 2011. Impact of hydrogeological low flows and groundwater drainage by lignite open cast mine on aquifer systems of gniezno Lakeland. Biuletyn - Panstwowego Instytutu Geologicznego, 445(2): 513-528. (in Polish)

Ptak M, Choiński A, Strzelczak A et al., 2013. Disappearance of lake Jelenino since the end of XVIII century as an effect of anthropogenic transformations of natural environment. Polish Journal of Environmental Studies, 22(1): 191-196. 
Rodríguez-Rodríguez M, Green A J, López R et al., 2012. Changes in water level, land use, and hydrological budget in a semi-permanent playa lake, Southwest Spain. Environmental Monitoring and Assessment, 184(2): 794-810.

Salmi T, Määttä A, Anttila P et al., 2002. Detecting trends of annual values of atmospheric pollutants by the Mann-Kendall test and Sen's slope estimates: The Excel template application MAKESENS. Air Quality, 31, Finnish Meteorological Institute, 35.

Schmid M, Hunziker S, Wüest A, 2014. Lake surface temperatures in a changing climate: A global sensitivity analysis. Climatic Change, 124(1/2): 301-315.

Shi W, Wang M, Guo W, 2014. Long-term hydrological changes of the Aral Sea observed by satellites. Journal of Geophysical Research: Oceans, 119(6): 3313-3326.

Singh C R, Thompson J R, French J R et al., 2010. Modelling the impact of prescribed global warming on runoff from headwater catchments of the Irrawaddy River and their implications for the water level regime of Loktak Lake, northeast India. Hydrology and Earth System Sciences, 14(9): 1745-1765.

Skibniewski L, 1954. Wahania poziomów zwierciadła wody większych jezior Pojezierza Pomorskiego i Mazurskiego. Przegląd Meteorologiczny, VII, 3-4.

Vincent C E, Davies T D, Beresford A K C, 1979. Recent changes in the level of Lake Naivasha, Kenya, as an indicator of equatorial westerlies over East Africa. Climatic Change, 2(2): 175-189.

Wilhelm S, Adrian R, 2008. Impact of summer warming on the thermal characteristics of a polymictic lake and consequences for oxygen, nutrients and phytoplankton. Freshwater Biology, 53: 226-237.

Wrzesiński D, Choiński A, Ptak M, 2015. Effect of the North Atlantic Oscillation on the thermal characteristics of lakes in Poland. Acta Geophysica, 63(3): 863-883. doi: 10.1515/acgeo-2015-0001.

Yao X, Liu S, Li L et al., 2014. Spatial-temporal characteristics of lake area variations in Hoh Xil region from 1970 to 2011. Journal of Geographical Sciences, 24(4): 689-702.

Yildirim Ü, Erdoğan S, Uysal M, 2011. Changes in the coastline and water level of the Akşehir and Eber lakes between 1975 and 2009. Water Resources Management, 25(3): 941-962.

Yin Y, Chen Y, Yu S et al., 2013. Maximum water level of Hongze Lake and its relationship with natural changes and human activities from 1736 to 2005. Quaternary International, 304(5): 85-94.

Zhuang C, Ouyang Z, Xu W et al., 2011. Impacts of human activities on the hydrology of Baiyangdian Lake, China. Environmental Earth Sciences, 62(7): 1343-1350.

Zinke P, Bogen J, 2013. Effect of water level regulation on gradients and levee deposits in the Lake Øyeren delta, Norway. Hydrology Research, 44(3): 523-537.

Ziverts A, Apsite E, 2005. Simulation of daily runoff and water level for the Lake Butrnieks. Simulation in Wider Europe - 19th European Conference on Modelling and Simulation, ECMS 2005, 633-637.

Zmijewski K, Becker R, 2014. Estimating the effects of anthropogenic modification on water balance in the Aral Sea watershed using GRACE: 2003-12. Earth Interactions, 18(3): 1-16.

Zolár P, Bengtsson L, 2006. Long-term and extreme water level variations of the shallow Lake Poopó, Bolivia. Hydrological Sciences Journal, 51(1): 98-114. 